\title{
Corporate Social Responsibility in Large Family and Founder Firms
}

\author{
Joern Block and Marcus Wagner
}

\begin{tabular}{|l|l|}
\hline \multicolumn{2}{|l|}{ ERIM REPORT SERIES RESEARCH IN MANAGEMENT } \\
\hline ERIM Report Series reference number & ERS-2010-027-ORG \\
\hline Publication & June 2010 \\
\hline Number of pages & 44 \\
\hline Persistent paper URL & http://hdl.handle.net/1765/20273 \\
\hline Email address corresponding author & block@ese.eur.nl \\
\hline Address & Erasmus Research Institute of Management (ERIM) \\
& RSM Erasmus University / Erasmus School of Economics \\
& Erasmus Universiteit Rotterdam \\
& P.O.Box 1738 \\
& 3000 DR Rotterdam, The Netherlands \\
& Phone: + 31 10 408 1182 \\
& Fax: + 31 10 408 9640 \\
& Email: info@erim.eur.nl \\
& Internet: $\quad$ www.erim.eur.nl \\
\hline
\end{tabular}

Bibliographic data and classifications of all the ERIM reports are also available on the ERIM website: www.erim.eur.nl 


\section{ERASMUS RESEARCH INSTITUTE OF MANAGEMENT}

\section{REPORT SERIES}

\section{RESEARCH IN MANAGEMENT}

\begin{tabular}{|l|l|}
\hline \multicolumn{2}{|l|}{ ABSTRACT AND KEYWORDS } \\
\hline Abstract & $\begin{array}{l}\text { Based on arguments about long-term orientation and corporate reputation, we argue that family } \\
\text { and founder firms differ from other firms with regard to corporate social responsibility. Using } \\
\text { Bayesian analysis, we then show that family and founder ownership are associated with a lower } \\
\text { level of corporate social responsibility concerns, whereas ownership by institutional investors is } \\
\text { associated with a higher level of corporate social responsibility concerns and a lower level of } \\
\text { corporate social responsibility initiatives. We conclude that it makes sense to distinguish } \\
\text { between family, founder and institutional investors and their roles as owners or managers when } \\
\text { analyzing the effects of corporate governance on corporate social responsibility. }\end{array}$ \\
\hline Free Keywords & $\begin{array}{l}\text { family firms, corporate social responsibility, founder firms, family ownership, family management, } \\
\text { long-term orientation }\end{array}$ \\
\hline Availability & $\begin{array}{l}\text { The ERIM Report Series is distributed through the following platforms: } \\
\text { Academic Repository at Erasmus University (DEAR), DEAR ERIM Series Portal } \\
\text { Social Science Research Network (SSRN), SSRN ERIM Series Webpage } \\
\text { Research Papers in Economics (REPEC), REPEC ERIM Series Webpage }\end{array}$ \\
\hline Classifications & $\begin{array}{l}\text { The electronic versions of the papers in the ERIM report Series contain bibliographic metadata } \\
\text { by the following classification systems: } \\
\text { Library of Congress Classification, (LCC) LCC Webpage } \\
\text { Journal of Economic Literature, (JEL), JEL Webpage } \\
\text { ACM Computing Classification System CCS Webpage } \\
\text { Inspec Classification scheme (ICS), ICS Webpage }\end{array}$ \\
\hline
\end{tabular}




\title{
CORPORATE SOCIAL RESPONSIBILITY
}

\section{IN LARGE FAMILY AND FOUNDER FIRMS}

\author{
Joern Block (a), Marcus Wagner (b)
}

(a) Erasmus University Rotterdam, School of Economics, Department of Applied Economics, P.O. Box 1738, 3000 DR Rotterdam, Netherlands, e-mail: block@ese.eur.nl, Tel.: +31 10 408 1004, Fax: +31 10408 9640; Technische Universität München, Schöller Chair in Technology and Innovation Management, Arcisstr. 21, 80333 München, Germany.

(b) Julius-Maximilians-Universität Würzburg, Chair in Entrepreneurship and Corporate Growth, Stephanstraße 1, 97070 Würzburg, Germany, e-mail: marcus.wagner@uni-wuerzburg.de; Tel.: +49 931 89046, Fax: +49 931 87263; Bureau d'Economie Théorique et Appliquée, Université de Strasbourg, 61 av. de la Fôret Noire, 68000 Strasbourg.

\begin{abstract}
Based on arguments about long-term orientation and corporate reputation, we argue that family and founder firms differ from other firms with regard to corporate social responsibility. Using Bayesian analysis, we then show that family and founder ownership are associated with a lower level of corporate social responsibility concerns, whereas ownership by institutional investors is associated with a higher level of corporate social responsibility concerns and a lower level of corporate social responsibility initiatives. We conclude that it makes sense to distinguish between family, founder and institutional investors and their roles as owners or managers when analyzing the effects of corporate governance on corporate social responsibility.
\end{abstract}

JEL codes: M10, M14

Keywords: Family firms, corporate social responsibility, founder firms, family ownership, family management, long-term orientation

Acknowledgements: The authors would like to thank Thomas Daffner, Andreas Riemann, Gaurav Rishi, Frank Spiegel, and Marc Weiglein for excellent help with data collection. This research was supported by the Deutsche Forschungsgemeinschaft through the SFB 649 "Economic Risk" and the individual grant "Long-term Orientation in Family Firms".

Corresponding author: Marcus Wagner; e-mail: marcus.wagner@uni-wuerzburg.de. 


\title{
CORPORATE SOCIAL RESPONSIBILITY IN \\ LARGE FAMILY AND FOUNDER FIRMS
}

\begin{abstract}
Based on arguments about long-term orientation and corporate reputation, we argue that family and founder firms differ from other firms with regard to corporate social responsibility. Using Bayesian analysis, we then show that family and founder ownership are associated with a lower level of corporate social responsibility concerns, whereas ownership by institutional investors is associated with a higher level of corporate social responsibility concerns and a lower level of corporate social responsibility initiatives. We conclude that it makes sense to distinguish between family, founder and institutional investors and their roles as owners or managers when analyzing the effects of corporate governance on corporate social responsibility.
\end{abstract}

\section{INTRODUCTION}

The literature is unclear as to whether family firms or founder firms have a stronger longterm orientation relative to other firms. Anderson \& Reeb (2003), for example, argue that family firms are more willing to invest in long-term projects because they think across generations (see also Bertrand \& Schoar, 2006; James, 1999; Miller \& Le Breton-Miller, 2005, 2006; Le BretonMiller \& Miller, 2006; Porter, 1992). In contrast, Chandler (1990) suggests that for family firms, the "goal $[\ldots]$ appears to have been to provide a steady flow of cash flow to owners - owners who were also managers" (1990, p. 390), indicating that family firms espouse a short-term perspective. Similar arguments are also advanced by Claessens et al. (2000, 2002), Gomez-Mejia et al. (2001, 2009) and Morck \& Yeung (2003, 2004). 
We analyze the question of long-term orientation in family and founder firms from the perspective of corporate social responsibility (CSR). We argue that firms that follow a long-term strategy care more strongly about their stakeholders than do other firms (Davies et al., 2003; Fombrun, 1996; Fombrun \& Shanley, 1990; Neubaum \& Zahra, 2006), which should be reflected in a higher level of CSR. The study closest to ours is that of Dyer \& Whetten (2006) (hereafter Dyer/Whetten), who find that family firms have fewer CSR-related concerns than do other firms. Using a similar data set, we can confirm their basic results and are able to expand their analysis in a number of ways. Responding to the criticism of the Dyer/Whetten study raised by Wiklund (2006), we use a more fine-grained definition of family firms. In particular, we distinguish between lone founder firms (hereafter founder firms), family firms and other firms (Miller et al., 2007), as well as between the ownership and management dimensions of these firms (Klein et al., 2005). In addition, we include a large number of additional independent variables in our regression models, such as the industry-wide level of CSR and the percentage of ownership by institutional investors, which have been found to have an effect on CSR (Amato \& Amato, 2007; King \& Lenox, 2001, 2002; Neubaum \& Zahra, 2006; Ziegler et al., 2007). To alleviate the potential problem of multicollinearity, we use Bayesian analysis (Hahn \& Doh, 2006; Hansen et al., 2004) in addition to classical statistical analysis. In replicating the results presented by Dyer/Whetten with classical statistical analysis, we show that the inclusion of important control variables such as industry categories leads the Dyer/Whetten results to become nonsignificant, most likely due to a problem of multicollinearity. Using Bayesian analysis, which does not rely on null hypothesis significance testing and is thus more immune to multicollinearity problems than classical statistical analysis (Leamer, 1973), we can show that family and founder ownership as well as family management are positively associated with CSR. In contrast, we find that 
founder management and ownership by institutional investors are negatively associated with CSR.

The remainder of the paper is organized as follows. The next section uses corporate reputation theory and the concept of long-term orientation to develop hypotheses regarding the CSR behavior of family and founder firms. We then introduce our data set and Bayesian analysis, the method used in this paper. The section that follows shows our empirical results, which are then discussed in the subsequent section.

\section{THEORY}

\section{Corporate reputation theory}

Corporate reputation theory has been developed and analyzed within various disciplines, including strategy, marketing, corporate communication and public relations. Mahon (2002) combines these separate literature streams. Corporate reputation as a concept builds on the idea that an audience assigns a positive reputation to a firm that appears to have desirable characteristics (Davies et al., 2003; Fombrun, 1996). Two key premises underlie this idea. First, people view firms as separate social entities rather than as a collective of individual actors (Hamilton \& Sherman, 1996; Whetten \& Mackey, 2002). Second, the audience is concerned about the firm's suitability as an exchange partner and puts a high value on characteristics such as trustworthiness and reliability (Freemann, 1984; Fombrun, 1996; Weigelt \& Camerer, 1988). Stakeholders (Freeman, 1984) evaluate the actions of a firm and use these actions to update their view of the firm and its character (Love \& Kraatz, 2009). If a firm makes a critical decision that is inconsistent with its communicated values and the historical commitments that it has made, this may be perceived as opportunistic behavior or unreliability, possibly changing the firm's reputation. 
The concept of and mechanisms behind corporate reputation theory essentially stress reputation-building based on social responsibility (Waldman et al., 2006). In this effort, providing feedback to customers, regulators and other interested stakeholders about the environmental quality and social benefits of products and processes through information dissemination, labeling and other means of signaling becomes increasingly important for firms hoping to realize economic benefits (Boer, 2003; Karl \& Orwat, 1999; Riley, 2001).

For example, Turban \& Greening (1997) show that signaling high levels of CSR enables firms to recruit more innovative and motivated employees. To the degree that environmentally concerned employees self-select into appropriate firms, labeling and similar activities aimed at signaling high levels of CSR enable a firm to strengthen a reputation of endorsing corporate sustainability.

It has been argued that CSR activities at firms are ultimately aimed at building reputationbased intangible assets (Arora \& Gangopadhyay, 1995). The literature also stresses that the ability to provide positive signals of this reputation to stakeholders is becoming increasingly important for firms (Shapiro, 1983; Kirchhoff, 2000). This is especially true for family firms that, due to limited career perspectives, may have difficulty recruiting talented employees (Dyer, 1989; Levinson, 1971).

Conversely, negative signals about environmental or social performance imply negative effects on reputation, that is, the destruction of reputation-based intangible assets (Jones \& Rubin, 2001). For example, in a recent empirical study, Love \& Kraatz (2009) show that through downsizing, firms lost more than two-thirds of their position in corporate reputation rankings on average (see also Flanagan \& O’Shaughnessy, 2005; Zyglidopoulos, 2004). 
Having established the relevance of corporate reputation as a theoretical basis, we argue in the following that family owners and managers identify more strongly with the firm than do nonfamily owners and managers. This stronger degree of identification makes these individuals more concerned about corporate reputation. Family managers and owners aim to avoid actions that may damage the reputation of the firm and their own reputations as firm owners or managers.

As noted in the introduction, family business literature puts a great deal of emphasis on the definition of family firms. This concern relates to the distinction between the ownership and management dimensions of family firms (Klein et al., 2005) and the separation of family firms from founder firms (Miller et al., 2007). In the context of CSR, it is also important to distinguish family owners from other large shareholders, such as institutional investors (Simerly, 1995; Wiklund, 2006). We develop separate hypotheses for each of these categories relying on arguments from the corporate reputation literature.

\section{Family ownership and CSR}

Previous research suggests that family ownership fosters social responsibility (Block, 2010; Deniz \& Suarez, 2005; Stavrou et al., 2007; Uhlaner et al., 2004). Family owners should feel a greater degree of organizational identification and are often also interested in handing over the firm to other owners at a later point in time (Ashforth \& Mael, 1989; Riketta, 2005). They should therefore be more concerned about the reputation of the firm and thus be more inclined than other owners to avoid reputation-damaging corporate actions. Unlike other owners, firm owners are often easily identifiable by society at large and by the local community in which their firm is located: positive or negative reputation spillovers can occur (e.g., Astrachan, 1988; Carrigan \& 
Buckley, 2008; Uhlaner et al., 2004; Wiklund, 2006). Compared to other types of owners, they should therefore be more likely to care about their reputation for social responsibility in the community in which their firm is located and should also have a higher degree of interest in avoiding being connected with CSR concerns by the general public. In line with this argument, it would seem that positive CSR activities are desirable as a way to compensate for unavoidable CSR concerns.

Complementary to these considerations is the way in which family ownership enables the effective monitoring of management: family owners often have deep knowledge of the firm and its business activities (Ward, 2004), which reduces information asymmetries and allows effective monitoring (Demsetz, 1988; Fama, 1980). Family owners are also highly motivated to engage in effective monitoring because they are emotionally connected to the firm and its activities (Astrachan \& Jaskiewicz, 2008; Zellweger \& Astrachan, 2008).

Another important difference between family-owned firms and other firms is that the former pursue a more balanced goal set than the latter (Chrisman et al., 2003, Lee \& Rogoff, 1996; Steier, 2003). It has been suggested that this relates to ethical aspects (Adams et al., 1996), social performance (Deniz \& Suarez, 2005) and environmental performance (Walls et al., 2007). A corollary of this notion is that family-owned firms are more likely to have more CSR strengths and fewer CSR weaknesses relative to other firms. They are unlikely to forfeit their balanced goal set to focus on profit maximization or economic performance. A related argument is that family firms are more used to multi-stakeholder engagements. This has partly to do with the wider goal set that they have but is also related to the family ties within the firm as well as the stronger need for family firms to pursue such engagements to compensate for the disadvantages that they experience as compared to their competitors (e.g., the more limited career opportunities 
for young, high-potential individuals). Given their greater experience with multi-stakeholder engagements, family firms are more likely to be open to considering CSR issues and hence will more likely act to reduce CSR concerns and increase CSR strengths. Ultimately, these considerations lead to the following two hypotheses:

H1a: Family ownership is associated with a higher level of CSR strengths.

H1b: Family ownership is associated with a lower level of CSR concerns.

\section{Family management and CSR}

Family ownership and family management can have different effects on family firm strategy (Block, 2010; Klein et al., 2005). Thus, we develop separate hypotheses for family management and family ownership. Family managers identify more strongly with the firm as a social entity than do non-family managers, which is why they are more likely to be concerned about corporate reputation. This more intense concern leads them to avoid developments that will have a negative effect on corporate reputation (Flanagan \& O'Shaughnessy, 2005; Love \& Kraatz, 2009; Zyglidopoulos, 2004). Due to their strong bonds with the firm and its history, family managers are less likely to consider outside options than are non-family managers. Family managers do not compete on the market for executives, and therefore they are less inclined to maximize the financial performance of the firm as a signal to this market (Block, 2010; Campbell and Marino, 1994). In addition, due to family bonds, family managers cannot easily leave their firm, which is why they have to bear any negative reputation caused by low levels of CSR. Thus, as long as the firm does not run the immediate risk of bankruptcy, a family manager will try to avoid actions that damage the firm's reputation. 
Also, the literature proposes that family managers have stronger positions in firms than do outside, non-family managers (Allen \& Panian, 1984; Jacobs, 1991; James, 1999) and thus that higher shares of family managers enable better implementation of the family's priorities and objectives (Le Breton-Miller \& Miller, 2009; Wiklund, 2006). Given that in the preceding section, a generally positive stance towards CSR on the part of families as owners (Habbershon et al., 2003; Pearson et al., 2008) was established, this argument implies an additional positive association between family management and the implementation of CSR strengths.

Based on these corporate reputation arguments, it can be proposed that family management leads to a stronger stewardship orientation within a firm (Le Breton-Miller \& Miller, 2009), of which a stronger CSR orientation would be one element. In addition, the involvement of family members in firm management increases the breadth and extent of interaction between the owning family and the different stakeholders of the firm. Assuming that this interaction also increases the CSR demands posed to the family, having family members in management positions should be associated with the creation of more CSR strengths and the avoidance of more CSR concerns than in other firms. We therefore propose the following two hypotheses:

H2a: Having a family CEO is associated with a higher level of CSR strengths after controlling for the effect of family ownership.

H2b: Having a family CEO is associated with a lower level of CSR concerns after controlling for the effect of family ownership.

\section{Founder firms and CSR}


Moving beyond the considerations of family ownership and family management, Miller et al. $(2007,2010)$ suggest distinguishing between lone founders and businesses with more than one family member involved. They find that founder firms are younger, have better market valuations and faster sales growth rates and spend more on R\&D and capital goods than do family firms.

The arguments concerning the effect of founder ownership on CSR are similar to those regarding the effect of family ownership on CSR (Dyer \& Whetten, 2006). The negative reputational aspects of CSR concerns should have implications for founders as owners that are similar to those for families as owners. Still, family owners differ from founders as owners in a number of respects that may affect CSR behavior: family firms are often plagued by conflicts between members of the owning family (e.g., Chrisman et al., 2005; Levinson, 1971), a problem that is non-existent with lone founders as owners. This potentially gives lone founder managers an even stronger position than family managers in a family-owned firm in implementing proactive CSR initiatives that increase CSR strength and reduce CSR concerns. However, it is unclear whether lone founder managers will exercise their power in this direction. Previous studies have noted a strong entrepreneurial spirit and growth orientation on the part of founder firms (Miller et al., 2010), which may lead to more CSR concerns and fewer CSR initiatives.

Miller et al. (2010) note an important difference between family and founder firms: family owners or family managers have to deal with family stakeholders and their 'familial' logic, which lends itself to conservation. Lone founder owners or managers deal with a broader set of stakeholders and are hence more market-driven. They express a stronger entrepreneurial orientation. If this argument is correct, then lone founders as managers are more financially motivated and are driven by a more commercial agenda than family managers. The degree to which they 
embrace CSR depends more strongly on the costs and benefits to the firm, and the demands of stakeholders are of lesser importance. Lone founder managers will tend to avoid costly CSR activities that have a negative effect on the firm's growth potential.

Previous literature has found that implementing CSR strengths is more initially costly than avoiding CSR concerns (Hart, 1995). Avoiding CSR concerns today is mostly a hygiene factor and often relates to industry standards or minimum performance levels expected by the public opinion (Figge et al., 2002). Often, low-cost, standardized solutions exist. The situation is different for CSR strengths, where individual solutions need to be developed. We argue that lone founders and managers will do what is necessary to avoid CSR concerns but will not invest in CSR strengths if that investment limits firm growth. This leads us to the following hypotheses:

H3a: Lone founder ownership is associated with a lower level of CSR strengths.

H3b: Lone founder ownership is associated with a lower level of CSR concerns.

H3c: Having a lone founder CEO is associated with a lower level of CSR strengths.

H3d: Having a lone founder CEO is associated with a lower level of CSR concerns.

\section{Institutional investors and CSR}

Institutional ownership is strongly debated in the context of CSR (Spicer, 1978; Neubaum \& Zahra, 2006). Institutional investors pool large sums of money and invest those sums in firms. These institutions include banks, insurance companies, pension funds, hedge funds and mutual funds. About $60 \%$ of total equity is owned by institutional investors (e.g., mutual funds or pension funds) that have highly diversified portfolios including a limited stake in 
each firm (Simerly, 1995). The average holding time for shares is often less than two years (Laverty, 1996; Porter, 1992). Institutional investors often focus on financial goals in the near term. They base their investment choices on limited information oriented towards predicting short-term stock price movements and focused on easily measurable figures such as the firm's current earnings or market value. Ultimately, the funds supplied by institutional investors move rapidly between firms (Jacobs, 1991).

It has been argued that the engagement of institutional investors leads to increased shorttermism (Freeman, 1984; Laverty, 1996), which in turn negatively affects the implementation of costly CSR policies, stifling many CSR initiatives that are not cost-efficient. When firms invest in CSR strengths beyond the minimum level legally required, improving corporate image or the ability to recruit excellent staff often emerge as important motivations. Such motivations are difficult to assess in terms of their economic benefits, and often, an attempt at an evaluation is not even made. This leads to the positive effects of such investments' being overlooked or (even worse) purposefully neglected because limited managerial resources are allocated to the evaluation of such benefits. These considerations suggest that the benefits of CSR investments are likely underestimated or remain partly uncovered. Because the economic benefits of investing in CSR strengths are difficult to estimate, it is often perceived that CSR has a net cost and is to be avoided, especially if investment horizons are short, as in the case of institutional investors.

In addition to these "short-termism"-related considerations, Wiklund (2006) points out that the enforcement of sanctions against institutional investors is difficult. The reason is that the shareholdings of these investors are often diluted. Unlike other large shareholders such as families or founders, the ultimate owners are difficult to identify. We propose the following two hypotheses: 
H4a: Institutional ownership is associated with a lower level of CSR strengths.

H4b: Institutional ownership is associated with a higher level of CSR concerns.

\section{SAMPLE AND VARIABLES}

\section{Sample}

The empirical part of this study is based on US data. The Standard \& Poor's 500 firms (as of July 31,2003 ) are the starting point for constructing the sample. The date chosen corresponds to an issue of BusinessWeek in which family firms in the S\&P 500 were indicated (BusinessWeek, 2003). ${ }^{1}$ We used this publication as a starting point since it provides useful qualitative information on the ownership structures and management compositions of the 177 family firms covered.

For the S\&P 500 firms, we collected detailed data about the firms' ownership structures and management compositions from corporate proxy statements submitted to the US Securities and Exchange Commission (SEC) in the years 1994-2003. This information was mostly found in the definitive proxy statement (DEF 14A). The Securities Exchange Act of 1934 requires officers, directors, and five-percent owners to disclose their holdings. Proxy statements are the most accurate source of information about ownership structures. In particular, proxy statements are more accurate than databases such as Compact Disclosure, which have some mistakes and biases (Anderson \& Lee, 1997; Dlugosz et al., 2006). We then checked and expanded the data with information from Hoover's Handbook of American Business, Gale Business Resources, the Twentieth-Century American Business Leaders Database at Harvard Business School, Forbes Lists of

1 BusinessWeek (2003) defines any "company where founders or descendants continue to hold positions in top management, on the board, or among the company's largest stockholders" (p. 111) as a family firm. The definition is very similar to Anderson and Reeb (2003). 
the 400 Richest Americans, Marquis Who's Who in America, and information available on the firms' websites. In a final step, the database Compustat was used to obtain the additional firm data used.

To obtain corporate social responsibility data, we relied on data from the social performance rating service Kinder, Lydenberg, and Domini (KLD). ${ }^{2}$ KLD rates the social performance of the S\&P 500 firms since 1991 and has been used in many scientific publications (McWilliams \& Siegel, 2000; Waddock \& Graves, 1997). Combining the KLD data with our manually collected data about the firm's ownership and management structures leads to an unbalanced panel dataset with 2,222 observations from 406 firms. The reduction in the number of observations per firm is due to the fact that some firms were not listed on the stock market over the entire period from 1994-2003.

\section{Variables}

\section{Dependent variables}

As concerns our dependent variables, Wood (1991, p. 693) defined corporate social policy (CSP) as “a business organization's configuration of principles of social responsibility, processes of social responsiveness, and policies, programs, and observable outcomes as they relate to the firm's societal relationships". Whilst this definition refers to a wide range of aspects such as the integration of such processes, principles or programs with cross-business functions (e.g., Wagner, 2007), one approach frequently pursued is to interpret activities and outcomes relating to CSR as a proxy for CSP (e.g., Dyer \& Whetten, 2006; Orlitzky, 2001). Since the KLD data cover a wide range of activities and outcomes related to CSR, the data are well suited to analyze CSR. The basic independent variables of CSR initiatives and concerns correspond to those used

2 See http://www.kld.com/Academic (accessed January $21^{\text {st }}, 2010$ ). 
in the Dyer/Whetten study. Adhering to their measurements helps us to replicate their findings and is a benchmark from which we can expand our analysis.

More specifically, we use two dependent variables in our analysis: (1) CSR concerns (defined as the sum of community, diversity, employee, environmental, non-US operations, product, and other concerns) and (2) CSR initiatives (defined as the sum of community, diversity, employee, environmental, non-US operations, product, and other initiatives). A high value (low value) of the variable CSR concerns (CSR initiatives) corresponds to irresponsible social management.

\section{Independent variables}

Going beyond the replication of the results from Dyer/Whetten, we incorporate additional control variables in our analysis and refine the definition of family- and founder firms.

Variables related to our hypotheses. The variables ownership by lone founder, ownership by family, and ownership by institutional investors measure the percentages of common equity owned by founders, families, and institutional investors, respectively. The distinction between lone founder firms and family firms was introduced by Miller et al. (2007). Our classification is similar. Lone founder owners are defined as owners in which an owner is one of the founders and none of his/her family members are involved as owners. Family owners, by contrast, are defined as owners in which at least two members of the founding family are active in the firm as owners. Institutional investors are large banks, insurance companies, mutual funds, private equity firms, and large individual financial investors. The variable family CEO is an indicator variable that equals one if a member of the founding family is CEO; the variable lone founder CEO is an indicator variable which equals one if the founder serves as the CEO of the firm. 
Control variables. We include the mean industry level of CSR initiatives and the mean industry level of CSR concerns in our analysis. Several studies have revealed that CSR is an industry-specific variable and that not controlling for industry effects may lead to biased results (King \& Lenox, 2001, 2002; Ziegler et al., 2007). Furthermore, achievable levels of environmental performance are closely tied to the firm's industry, for example in terms of air pollution and energy consumption. Also, public scrutiny with regard to CSR is industry-specific, and hence it can be expected that also firms' reactions to scrutiny will differ across industries. ${ }^{3}$ Next to these industry control variables, we also include firm size as a control variable. Extant literature has shown that firm size influences the level of environmental or social activities by a firm (e.g., Amato \& Amato, 2007; Lepoutre \& Heene, 2006; Stanwick \& Stanwick, 1998). The larger a firm, the higher is also its level of CSR engagement. Furthermore, a positive link is suggested between size and visibility, which indirectly affects the firm's level of CSR engagement (Brammer \& Millington, 2006; Gan, 2006; Henriques \& Sadorsky, 1996). In sum, it is necessary to control for firm size to avoid an omitted variables bias. Firm size is measured by the natural logarithm of the firm's total assets. In addition to firm size, we also control for the firm's capital structure (variable debt/assets) and the firm's profitability (variable return on assets). All variables are described in more detail in Table A1 in the appendix.

\section{METHOD: BAYESIAN ANALYSIS}

\footnotetext{
3 In a variant of our analysis, we also include industry dummies instead of industry means. The main estimation results however remain unchanged. The results are available from the authors on request.
} 
We test our hypotheses with both classical and Bayesian analysis. Since Bayesian methods are not widely used in management research, we describe the method in some detail. ${ }^{4}$ Bayesian analysis relies on Bayes' theorem of probability theory (Bayes, 1763). This theorem is given by

$$
\operatorname{Pr}(\theta \mid y)=\frac{\operatorname{Pr}(y \mid \theta) \operatorname{Pr}(\theta)}{\operatorname{Pr}(y)}
$$

where $\theta$ represents the set of unknown parameters, and $y$ represents the data. $\operatorname{Pr}(\theta)$ is the prior distribution of the parameter $\theta$, which may be derived from theory, expert opinion, or other external resources. $\operatorname{Pr}(y \mid \theta)$ is the likelihood function, which represents the probability of the data $y$ given the unknown parameter $\theta . \operatorname{Pr}(y)$ is the marginal distribution of the data $y$, and $\operatorname{Pr}(\theta \mid y)$ represents the posterior distribution, which is the probability of the parameter $\theta$ given the data $y$. Equation (1) may also be written as

$$
\operatorname{Pr}(\theta \mid y) \propto \operatorname{Pr}(y \mid \theta) \operatorname{Pr}(\theta),
$$

where $\propto$ means "proportional to." The posterior distribution is proportional to the likelihood function times the prior distribution. In Bayesian analysis, inference derives from the posterior distribution, which states the likelihood of a particular parameter assuming a certain value. Bayesian methods can be particularly useful for testing theory. When testing a hypothesized relationship between two variables, Bayesian analysis proceeds according to the following process: first, a priori beliefs (from theory or other external resources) about the relationship of interest

\footnotetext{
4 See The Economist (2000) for a general discussion of Bayesian methods. Hahn and Doh (2006) and Hansen et al. (2004) discuss the potential contributions of Bayesian methods in management research.
} 
are formulated (the prior distribution, $\operatorname{Pr}(\theta)$ ). Next, we assume a probability of occurrence of our observed data given these a priori beliefs (the likelihood function, $\operatorname{Pr}(y \mid \theta)$ ). In a second step, our observed data is used to update these beliefs. The result is the posterior distribution, $\operatorname{Pr}(\theta \mid y)$. This posterior distribution leads to a probability density function that expresses the relationship between the two variables. This allows for statements in terms of likely and unlikely parameter values. This process highlights the fundamental difference between classical and Bayesian methods. Bayesian analysis does not assume that there exist true and fixed coefficients; instead, the coefficients are regarded as being stochastic.

In recent years, Bayesian methods have become increasingly adopted in research. First applied in macroeconomics and decision theory, Bayesian methods have become popular in other social sciences, notably marketing research. ${ }^{5}$ Few Bayesian studies, however, have been conducted in management research contexts. A rare example is Hansen et al. (2004), who use a Bayesian approach to operationalize the resource-based view. Bayesian methods have strong small sample properties and are less sensitive to problems of multicollinearity (Hahn \& Doh, 2006; Leamer, 1973). The reason is that Bayesian methods do not rely on asymptotic theory but instead offer the likelihood that a particular coefficient has a positive value. The result of the Bayesian estimation, namely the posterior distribution, makes a statement as regards to which coefficient values are likely and which are not. If multicollinearity is present, the posterior will still reflect the updated beliefs of the posterior distribution. If anything can be learned from the data, it will be reflected in the posterior distribution.

We use Bayesian methods in addition to classical methods, because they allow us making exact probability statements about the effects of family- and founder-related variables on corpo-

5 Rossi \& Allenby (2003) discuss the potential contributions of Bayesian statistics in the field of the latter. 
rate social responsibility. For example, we can state the probability that family ownership or management leads to more social responsibility initiatives. Such a statement is not possible with classical methods, which can only make a statement as to whether a particular variable has an effect or not (i.e., the variable is significant or not). Thus, Bayesian methods can account for the large heterogeneity that exists in the group of family and founder firms (Klein et al., 2005).

The technical details of our Bayesian analysis are described in appendix A3.

\section{RESULTS}

\section{Univariate analysis}

Table 1 shows the results of a univariate analysis of the CSR of family-/founder-owned firms relative to other firms. Family-owned firms are defined as firms in which at least one member of the founding family owns five percent of common equity; founder-owned firms are defined as firms in which the founder(s) own(s) at least five percent of common equity. We compare the three types of firms on both the aggregate level of CSR concerns/initiatives and on the level of more fine-grained categories (e.g., community concerns/initiatives or environmental concerns/initiatives).

\section{Table 1 about here}

CSR initiatives. In line with Dyer/Whetten, we find no significant differences between CSR initiatives in family-owned firms/founder-owned firms and other firms on the aggregate level. Also, for all except two categories (or in the case of founder firms, four categories), we find no significant differences at the 5\% significance level. The significantly different categories are en- 
vironmental initiatives and other initiatives (for founder firms, there are also product initiatives and community initiatives). In summary, the results of our analysis of the distinction between founder and family firms showed little difference from the results of Dyer/Whetten on the aggregate level but produced different results on the more fine-grained category level.

CSR concerns. Dyer/Whetten found a significant difference between the levels of CSR concerns in family and nonfamily firms on the aggregate level. Our findings confirm the significant differences on the aggregate level for both family-owned firms and founder-owned firms. On the category level, we find significant differences for product concerns (only family-owned firms), environmental concerns and employee concerns (only family-owned firms) as well as for community concerns. Again, as with CSR initiatives, our findings are similar to those of Dyer/Whetten.

\section{Multivariate analysis}

\section{Results from classical regressions}

In the classical regressions, we proceed in a manner similar to that of Dyer/Whetten. In particular, we use similar variables in our regression model and estimate random-effects models. Table A2 shows a correlation matrix of the variables used in the regressions. Except in the case of the management and ownership variables, there is little correlation among the independent variables. Multicollinearity may only be an issue when distinguishing between the management and ownership dimensions of family and founder firms. Tables 2 and 3 show the results of the classical regressions.

Tables 2 and 3 about here 
Replication of Dyer/Whetten: Model I in Tables 2 and 3 is specified in a way similar to that of Dyer/Whetten. ${ }^{6}$ Not surprisingly, we can reproduce their main findings. Combining founder ownership and family ownership into one variable, we find a significant negative association between that variable and the number of CSR concerns and a non-significant relationship with the number of CSR initiatives.

Extension of Dyer/Whetten. As noted above, research on the environmental impacts of firms stresses the large industry sector variation in CSR (Amato \& Amato, 2007; Henriques \& Sadorsky, 1996). If industry is not controlled for, an omitted variables bias may emerge. Thus, we extend the model of Dyer/Whetten by including the mean levels of CSR initiatives and CSR concerns per industry per year as additional control variables (Model II in Tables 2 and 3). This modification to the model has an important effect: the relationship between family/founder ownership and the number of CSR concerns is no longer significant, while the newly introduced industry variables are highly significant. The key result of Dyer/Whetten disappears once industry effects are controlled for in the analysis. The explanatory power of the respective regressions also increases greatly: the $\mathrm{R}^{2}$-value of the CSR concerns regression increases from $21 \%$ to $47 \%$ (Table 2), while the $\mathrm{R}^{2}$-value of the CSR initiatives regression increases from $12 \%$ to $28 \%$ (Table 3).

Next to the issue of missing important control variables, Wiklund (2006, p. 806) points to the definition of what constitutes a family firm as a key element at play: "Implicit in the argument by Dyer \& Whetten (2006) are three aspects of family business [...] the degree of unification of ownership and management $[\ldots]$ share of the family's wealth tied to the performance of

We also estimated regressions with the BusinessWeek (2003) family firm definition used by Dyer/Whetten and still reproduce their results in this way, but we do not report detailed estimates here for reasons of brevity. The results are, however, available upon request. 
the firm [...] ability of the family to liquidate its investment in the firm. [...] an explicit measurement of the dimensions would benefit family business research". We fully concur with this statement and use more fine-grained family and founder variables. We distinguish between family and founder involvement (Model III, Tables 3-4) as well as between the management and ownership dimensions of these two types of firms (Model IV, Tables 3-4). The results do not change substantially from those arrived at using Model II. None of the four family/founder variables have any significant association with the level of social responsibility concerns/initiatives. Also, the explanatory power of the model remains unchanged. The family variables closest to statistical significance are family ownership for CSR concerns ( $\mathrm{p}=0.11$, two-sided test) and family CEO for CSR initiatives ( $\mathrm{p}=0.12$, two-sided test).

As noted above, through the posterior distributions, Bayesian analysis can provide a more complete view of the effects of specific variables than can classical analysis. This more complete view may help to decrease the ambiguity in the results emerging from our classical regressions.

\section{Results from Bayesian regressions}

We estimated the regression models in Tables 2 and 3 using Bayesian methods. Generally, the results of Bayesian analyses are distribution functions, called the posterior distributions, of the effects of the variables included in the regressions. We report the medians of these distribution functions as well as the probability that the respective coefficient will have a positive value (Tables 4 and 5). In addition, we also graphically display the posterior distribution functions of the family and lone founder variables (Figures 1-8). In showing both the probability and the size of a particular effect, these graphical representations contain more information than do single metrics such as coefficient values in classical regressions. 
Tables 4 and 5 and Figures 1-8 about here

CSR concerns regressions. Table 4 displays the results of the CSR concerns regressions. Model I shows that the variable ownership by founder or family is negatively associated with the number of CSR concerns (median $\beta=-1.06$, probability of $\beta>0$ is $4.5 \%$ ). This effect does not change when the industry control variable is included (Model II). Model III differentiates between founder and family ownership: the negative effect is larger with founders as owners (median $\beta=-1.81$, probability of $\beta>0$ is $4.9 \%$ ) than with families as owners (median $\beta=-0.88$, probability of $\beta>0$ is $17.7 \%$ ). Finally, Model IV shows that the effects of ownership and management act in different directions. The variables lone founder $C E O$ (median $\beta=0.14$, probability of $\beta>0$ is $86.4 \%$ ) and family $C E O$ (median $\beta=0.34$, probability of $\beta>0$ is $99.2 \%$ ) have a positive impact on the level of CSR concerns, whereas the ownership variables have a negative impact.

CSR initiatives regressions. Table 5 displays the results of the CSR initiatives regressions. The variable ownership by founder or family has a positive impact on CSR initiatives (median $\beta=0.28$, probability of $\beta>0$ is $69.2 \%$, Model I). This effect does not change substantially when the industry control variable is included (median $\beta=0.16$, probability of $\beta>0$ is $62.0 \%$, Model II). The results of Models III and IV show that family firms and founder firms differ with respect to CSR initiatives: the variables ownership by family (median $\beta=0.48$, probability of $\beta>0$ is $79.1 \%$ ) and family $C E O$ (median $\beta=0.24$, probability of $\beta>0$ is $96.2 \%$ ) have a positive effect, whereas the variables ownership by founder (median $\beta=-1.65$, probability of $\beta>0$ is $7.0 \%$ ) and founder $C E O$ (median $\beta=-0.14$, probability of $\beta>0$ is $11.7 \%$ ) have a negative effect. 


\section{CONCLUSION AND DISCUSSION}

\section{Summary of main results}

We set out to analyze long-term orientation in family and founder firms by focusing on CSR, arguing that firms that adopt a long-term-oriented strategy should have relatively lower levels of CSR concerns and relatively higher levels of CSR strengths than other firms. We build hypotheses for both the ownership and management dimensions of family and founder firms.

Corporate governance in family firms is characterized by long CEO tenures (Le BretonMiller \& Miller, 2006; Tsai et al., 2006), effective monitoring (Chrisman et al., 2004; Demsetz, 1988; Fama, 1980) and low information asymmetries between the firm's ownership and management (Ward, 2004). These characteristics should have a positive impact on the firm's degree of long-term orientation (Le Breton-Miller \& Miller, 2006). In empirical studies, Stavrou et al. (2007) and Block (2010) find that family ownership is negatively associated with the likelihood and level of downsizing. We argue in this paper that a stronger long-term orientation on the part of family and founder firms should also lead to fewer CSR concerns and greater CSR strengths.

The starting point of our analysis is the study by Dyer/Whetten, whose results we replicate in our first step. In our next step, we then show that when controlling for industry-level averages of CSR strengths and CSR concerns, the influence of the ownership and management variables on CSR becomes much weaker. When we further distinguish between family and founder firms as well as between their ownership and management dimensions, the results become even less clear. Most importantly, family and founder firms are no longer associated with different levels of CSR as compared with other firms. As already suggested in the Dyer/Whetten study, these unclear findings are most likely due to multicollinearity problems. 
We therefore use Bayesian analysis (Hahn \& Doh, 2006; Hansen et al., 2004) to separate the effects of family and founder firms from the effects of control variables such as industry levels of CSR or ownership by financial investors. In doing so, we find that family and lone founder ownership is associated with having fewer CSR concerns than other firms, whereas lone founder and family management seems be associated with more CSR concerns. Overall, the Bayesian results support hypotheses H1a, H1b, H2a, H3a, H3c, H3d, H4a, and H4b.

\section{Family firms and CSR}

Family management and family ownership seem to have differing effects on CSR concerns, thus supporting the argument of Wiklund (2006) that family firms are a heterogeneous group with regard to CSR. Our results show that families in their roles as owners seem to avoid CSR concerns, whereas families in their roles as managers increase the level of CSR concerns. This can be explained by the different objectives of the two groups. Families as owners see the firm as a long-term investment in the tradition and heritage of the family. Even though they have a good understanding of the business and its needs, they are not as involved in the operational aspects of the firm. They care about the reputation of the firm and want to transfer the firm to the next generation. Moreover, relative to other large shareholders such as investment funds, they can be more easily identified by the public as business owners and thus have to bear the consequences if a negative image is associated with their firm. The situation is different with families as managers. Of course, families as managers must also bear the negative consequences associated with a negative firm reputation. However, unlike in their role as owners, families as managers are also evaluated in terms of operational qualities such as profitability and firm growth. In particular, large non-family shareholders at family-managed firms will carefully evaluate the performance 
of family managers. Often, family members are awarded positions as managers because of their status as family members (Allen \& Panian, 1982; Bennedsen et al., 2007), which is why they may feel that they are under pressure to justify their positions in the firm through superior financial results (and make subsequent compromises with regard to CSR engagement). These considerations indicate that family management can lead to lower levels of CSR relative to those at other firms.

\section{Founder firms and CSR}

Our results show that founder firms differ from family firms and other firms with regard to CSR. Relative to other firms, firms with founders as managers are associated with a lower level of CSR initiatives and a higher level of CSR concerns. This finding is in line with recent research by Miller et al. (2010). The negative association of founder management with CSR initiatives may be related to the fact that lone founders are very ambitious in expanding their business and hence require that most of the firm's resources be allocated to growth initiatives. They have built up the business themselves and use entrepreneurial logic to steer their firms. They care primarily about the business and how it can grow and remain competitive. Founders as managers care less about the needs of various outside stakeholder groups. Interestingly, we find that founder owners are associated with a lower level of CSR concerns. The explanation for this finding may be similar to that for the influence of families as owners. Compared to rather anonymous shareholders such as investment funds, founders as owners can be easily identified by the public as business owners. Thus, any negative image associated with a firm that has many CSR concerns spills over to them individually, whereas institutional investors as shareholders are less concerned with this association. Thus, to avoid spillover from a negative reputation, founders as owners will require 
the firm to do what is necessary to avoid CSR concerns. However, they have little ambition to score high in terms of CSR strengths. They will sacrifice building CSR strengths to use the

firm's resources for firm growth. This argument is consistent with the findings of previous research indicating that realizing CSR strengths is more expensive than avoiding CSR concerns. Moreover, avoiding concerns is in many cases a (legal or societal) requirement that needs to be fulfilled as part of "good housekeeping of corporate citizens" (whereas realizing CSR strengths is more often optional from a legal and societal standpoint).

\section{Institutional investors and CSR}

In this paper, we contribute to the discussion about the effects of institutional ownership on CSR (Neubaum \& Zahra, 2006; Simerly, 1995; Spicer, 1978). Ownership by institutional investors leads to more CSR concerns and fewer CSR initiatives relative to the number pursued by other firms. We explain this finding in two ways. First, as mentioned by Wiklund (2006), institutional investors as owners are more difficult to identify than are other large shareholders. For instance, investment funds bundle the investments of several thousand individuals. There is not a single individual or family that can be blamed if the firm is not fulfilling its obligation to its stakeholders to be socially responsible. Society finds it difficult to monitor the social behavior of these types of shareholders. Secondly, the incentives driving the management of an investment fund are focused on the short-term and are evaluated in terms of the return on investment (ROI) achieved for their investors. They will be promoted or qualify for bonus pay if they achieve ROIs superior to those of other investment funds. To do so, they will exert pressure on the management of their portfolio firms to pay out dividends or increase stock market value through strong financial results (Porter, 1992). The holding period for stocks for institutional investors is often 
short. In fact, these investors may even pursue short-term trading strategies such as buying or selling stock depending on short-term market movements (Froot et al., 1992; Johnson \& Kaplan, 1987; Laverty, 1996; Porter, 1992).

\section{Future research}

Our findings also cannot fully rule out the possibility of reverse or dual causality. Causality is not easily testable in empirical research, but several publications argue for reverse or dual causality in related contexts (e.g., Orlitzky \& Swanson, 2008; Ziegler \& Seijas-Nogareda, 2009; Wiklund, 2006). For example, Orlitzky \& Swanson (2008) show the existence of a reversecausal relationship between financial performance and social performance, suggesting that only firms with sufficient financial slack become involved in CSR programs and that firms that are financially successful are expected to express higher levels of CSR. Similarly, a 'noblesse oblige' view has been proposed regarding family-owned firms, in which it is theorized that normative pressure increases with improving financial performance and that family-owned firms often demonstrate better financial performance (Kepner, 1983). Wiklund (2006) argues that family firms have more of their wealth tied to firm reputation and therefore invest more to realize CSR strengths and avoid CSR concerns so as to maintain a good reputation and safeguard their financial wealth. Taken together with the earlier argument, this implies dual causality. Future research should therefore attempt to analyze this concept in greater detail in the context of family firms, especially with regard to the association of CSR with financial performance.

\section{REFERENCES}

Adams, J., Taschian, A. \& Shore, T. (1996). Ethics in family and nonfamily owned firms: An exploratory study. Family Business Review, 9(2), 157-170. 
Allen, M. P. \& Panian, S. K. (1982). Power, performance, and succession in the large corporation. Administrative Science Quarterly, 27(4), 538-547.

Amato, L. H. \& Amato, C. H. (2007). The effects of firm size and industry on corporate giving. Journal of Business Ethics, 72(3), 229-241.

Anderson, R. C. \& Lee, D. S. (1997). Ownership studies: the data source does matter. Journal of Financial and Quantitative Analysis, 32(3), 311-329.

Anderson, R. C. \& Reeb, D. R. (2003). Founding family ownership and firm performance: evidence from the S\&P 500. Journal of Finance, 58(3), 1301-1328.

Arora, S. \& Gangopadhyay, S. (1995). Toward a theoretical model of voluntary overcompliance. Journal of Economic Behavior and Organization, 28(3), 298-309.

Astrachan, J. H. (1988). Family firm and community culture. Family Business Review, 1(2), 165190.

Astrachan, J. H., \& Jaskiewicz, P. (2008). Emotional returns and emotional costs in privately held family businesses: advancing traditional business valuation. Family Business Review, 21(2), 139-149.

Bayes, T. (1763). An essay towards solving a problem in the doctrine of chances. Philosophical Transaction of the Royal Society of London, 53, 370-418.

Bennedsen, M. K, Nielsen, M. K., Pérez-González, F. \& Wolfenzon, D. (2007). Inside the family firm: the role of families in succession decisions and performance. Quarterly Journal of Economics, 122(2), 647-691.

Bertrand, M. \& Schoar, A. (2006). The role of family in family firms. Journal of Economic Perspectives, 20(2), 73-96.

Block, J. (2010). Family management, family ownership, and downsizing: evidence from S\&P 500 firms. Family Business Review, 23(2), 1-22.

Boer, J. de (2003). Sustainability labelling schemes: the logic of their claims and their functions for stakeholders. Business Strategy and the Environment, 12(4), 254-264.

Brammer, S. \& Millington, A. (2006). Firm size, organizational visibility and corporate philanthropy: an empirical analysis. Business Ethics: A European Review, 15(1), 6-18.

BusinessWeek. (2003). Family Inc. November 10, 111-114.

Campbell, T. S., Marino, A. M. (1994). Myopic investment decisions and competitive labor markets. International Economic Review, 35(4), 855-875.

Chandler, A. D. (1990). Scale and scope: the dynamics of industrial capitalism. Cambridge: Harvard University Press. 
Chrisman, J. J., Chua, J. H. \& Zahra, S. (2003). Creating wealth in family firms through managing resources: comments and extensions. Entrepreneurship Theory and Practice, 27(4), 359365.

Chrisman, J. J., Chua, J. H. \& Litz, R. A. (2004). Comparing the agency costs of family and nonfamily firms: conceptual issues and exploratory evidence. Entrepreneurship Theory and Practice, 28(4), 335-354.

Chrisman, J. J., Chua, J. H. \& Sharma, P. (2005). Trends and directions in the development of a strategic management theory of the family firm. Entrepreneurship Theory and Practice, $29(5), 555-575$.

Claessens, S., Djankov, S. \& Lang, L. H. P. (2000). The separation of ownership and control in East Asian corporations. Journal of Financial Economics, 58(1), 81-112.

Claessens, S., Djankov, S., Fan, J. P. H. \& Lang, L. H. P. (2002). Disentangling the incentive and entrenchment effects of large shareholdings. Journal of Finance, 57(6), 2741-2771.

Davies, G., Chun, R., Da Silva, R., \& Roper, S. (2003). Corporate Reputation and Competitiveness. London: Routledge.

Davis, J. H., Schoorman, F. D. \& Donaldson, L. (1997). Toward a stewardship theory of management. Academy of Management Review, 22(1), 20-47.

Demsetz, H. (1988). Ownership, control, and the firm. New York: Blackwell.

Deniz, D. \& Suarez, M. K. C. (2005). Corporate social responsibility and family business in Spain. Journal of Business Ethics, 56(1), 27-36.

Dyer, W. G. (1989). Integrating professional management into a family owned business. Family Business Review, 2(3), 221-235.

Dyer, W. G. \& Whetten, D. A. (2006). Family firms and social responsibility: preliminary evidence from the S\&P 500. Entrepreneurship Theory and Practice, 30(6), 785-802.

Dlugosz, J., Fahlenbrach, R., Gompers, P. \& Metrick, A. (2006). Large blocks of stock: prevalence, size and measurement. Journal of Corporate Finance, 12(3), 594-618.

Fama, E. F. (1980). Agency problems and the theory of the firm. Journal of Political Economy, $88(2), 288-307$.

Figge, F., Han, T., Schaltegger, S. \& Wagner, M. (2002) The Sustainability Balanced Scorecard - linking sustainability management to business strategy. Business Strategy and the Environment 11, 269-284.

Flanagan, D. J. \& O'Shaughnessy, K. C. (2005). The effect of layoffs on firm reputation. Journal of Management, 31(3), 445-463. 
Fombrun, C. J. (1996). Reputation: Realizing value from the corporate image. Boston: Harvard Business School.

Fombrun, C. J. \& Shanley, M. (1990). What's in a name: reputation building and corporate strategy. Academy of Management Journal, 33(2), 233-258.

Freeman, R.E. (1984). Strategic management: a stakeholder approach. Marshfield: Pitman.

Froot, K. A., Scharfstein, D. S. \& Stein, J. C. (1992). Herd on the street: international inefficiences in a market with short-term speculation. Journal of Finance, 47(4), 1461-1484.

Gan, A. (2006). The impact of public scrutiny on corporate philanthropy. Journal of Business Ethics, 69(3), 217-236.

Gomez-Mejia L. R. \& Berrone, P. (2009). Environmental performance and executive compensation: an integrated agency-institutional perspective. Academy of Management Journal, 52(1), 103-126.

Gomez-Mejia, L. R., Nunez-Nickel, M. \& Gutierrez, I. (2001). The role of family ties in agency contracts. Academy of Management Journal, 44(1), 81-95.

Hahn, J. \& Doh, J. P. (2006). Using Bayesian methods in strategy research: an extension of Hansen et al.. Strategic Management Journal, 27(8), 783-798.

Hamilton, D. L. \& Sherman, S. J. (1996). Perceiving persons and groups. Psychological Review, 103(2), 336-355.

Hansen, M., Perry, L. T. \& Reese, C. S. (2004). A Bayesian operationalization of the resourcebased view. Strategic Management Journal, 25(13), 1279-1295.

Hart, S. L. (1995). A natural-resource-based view of the firm. Academy of Management Review, 20(4), 986-1014.

Henriques, I. \& Sadorsky, P. (1996). The determinants of an environmentally responsive firm: an empirical approach. Journal of Environmental Economics and Management, 30(3), 381-395.

Jacobs, M. T. (1991). Short-term America: the causes and cures of our business myopia. Boston: Harvard Business School Press.

James, H. S. (1999). Owner as manager, extended horizons and the family firm. International Journal of the Economics of Business, 6(1), 41-55.

Johnson, H. T. \& Kaplan, R. S. (1992). Relevance lost. Boston: Harvard Business School Press.

Jones, K. \& Rubin, P. H. (2001). Effects of harmful environmental events on reputations of firms. Advances in Financial Economics, 6, 161-182. 
Karl, H. \& Orwat, C. (1999). Economic aspects of environmental labeling. In: Folmer, H., Tietenberg, T. (Eds.), The International Yearbook of Environmental and Resource Economics 1999/2000. Edward Elgar, Cheltenham (UK), 107-170.

Kepner, E. (1983). The family and the firm: a coevolutionary perspective. Organizational Dynamics, 12(1), 57-71.

King, A. \& Lenox, M. (2001). Does it really pay to be green? Journal of Industrial Ecology, 5(1), 105-116.

King, A. \& Lenox, M. (2002). Exploring the locus of profitable pollution reduction. Management Science, 48(2), 289-299.

Kirchhoff, S. (2000). Green business and blue angels: a model of voluntary overcompliance with asymmetric information. Environmental and Resource Economics, 15, 403-420.

Klein, S. B., Astrachan, J. H. \& Smyrnios, K. X. (2005). The F-PEC scale of family influence: construction, validation, and further implication for theory. Entrepreneurship Theory and Practice, 29(3), 321-339.

Koop, G. (2003). Bayesian econometrics. Chicester: Wiley.

Laverty, K. J. (1996). Economic "short-termism": the debate, the unresolved issues, and the implications for management practice and research. Academy of Management Review, 21(3), 825-860.

Leamer, E. E. (1973). Multicollinearity: a Bayesian interpretation. Review of Economics and Statistics, LV(3), 371-380.

Le Breton-Miller, I. \& Miller, D. (2009). Agency vs. stewardship in public family firms: a social embeddedness reconciliation. Entrepreneurship Theory and Practice, 33(6), 1169-1191.

Lee, M. S. \& Rogoff, E. G. (1996). Research note: comparison of small businesses with family participation versus family businesses without family participation: an investigation of differences in goals, attitudes, and family/business conflict. Family Business Review, 9(4), 423437.

Lepoutre, J. \& Heene, A. (2006). Investigating the impact of firm size on small business social responsibility: a critical review. Journal of Business Ethics, 67(3), 257-273.

Levinson, H. (1971). Conflicts that plague family businesses. Harvard Business Review, 49(March), 90-98.

Mahon, J. F. (2002). Corporate reputation. Research agenda using strategy and stakeholder literature. Business \& Society, 41(4), 415-445.

McWilliams, A. \& Siegel, D. (2000). Corporate Social Responsibility and Financial Performance: Correlation or Misspecification? Strategic Management Journal, 21(5), 603-609. 
Miller, D. \& Le Breton-Miller, I. (2005). Managing for the long run: lessons in competitive advantage from great family businesses. Boston: Harvard Business School Press.

Miller, D. \& Le Breton-Miller, I. (2006). Priorities, practices and strategies in successful and failing family businesses: an elaboration and test of the configuration perspective. Strategic Organization, 4(4), 379-407.

Miller, D., Le Breton-Miller, I., Lester, R. H. \& Cannella, A. A. (2007). Are family firms really superior performers? Journal of Corporate Finance, 13(5), 829-858.

Miller, D., Le Breton-Miller, I. \& Lester, R. (2010). Family and lone founder ownership and strategic behaviour. Journal of Management Studies, in press.

Morck, R. K. \& Yeung, B. (2003). Agency problems in large family business groups. Entrepreneurship Theory and Practice, 27(4), 367-382.

Morck, R. K. \& Yeung, B. (2004). Family control and the rent-seeking society. Entrepreneurship Theory and Practice, 28(4), 391-409.

Narayanan, M. P. (1985). Managerial incentives for short-term results. Journal of Finance, 40(5), 1469-1484.

Neubaum, D. O. \& Zahra, S. (2006). Institutional ownership and corporate social performance: the moderating effects of investment horizon, activism, and coordination. Journal of Management, 32(1), 108-131.

Orlitzky, M. (2001). Does firm size confound the relationship between corporate social performance and firm financial performance? Journal of Business Ethics, 33(2), 167-180.

Orlitzky, M. \& Swanson, D. L. (2008). Toward integrative corporate citizenship: Research advances in corporate social performance. London: Palgrave Macmillan.

Pearson, A. W., Carr, J. C., \& Shaw, J. C. (2008). Toward a theory of familiness: a social capital perspective. Entrepreneurship Theory and Practice, 32(6), 949-969.

Porter, M. E. (1992). Capital disadvantage: America's failing capital investment system. Harvard Business Review, 70(5), 65-82.

Riley, J.G. (2001). Silver signals: twenty-five years of screening and signaling. Journal of Economic Literature, 39(June), 432-479.

Rossi, P. E. \& Allenby, G. M. (2003). Bayesian statistics and marketing. Marketing Science, 22(3), 304-328.

Stavrou, E. T., Kassinis, G. \& Filotheou, A. (2007). Downsizing and stakeholder orientation among the Fortune 500: does family ownership matter? Journal of Business Ethics, 72(2), 149-162. 
Simerly, R. L. (1995). Institutional ownership, corporate social performance, and firms' financial performance. Psychological Reports, 77, 515-525.

Shapiro, C. (1983). Premiums for high quality products as returns to reputations. Quarterly Journal of Economics, 98(4), 659-679.

Spicer, B. H. (1978). Investors, corporate social performance and information disclosure: an empirical study. The Accounting Review, 53(1), 94-111.

Stanwick, P.A. \& Stanwick, S.D. (1998). The relationship between corporate social performance, and organizational size, financial performance, and environmental performance: an empirical examination. Journal of Business Ethics, 17(2), 195-204.

Steier, L. (2003). Variants of agency contracts in family financed ventures as a continuum of familial altruistic and market rationalities. Journal of Business Venturing, 18(5), 597-618.

The Economist. 2000. In praise of Bayes. September $28^{\text {th }}$.

Tsai, W. H., Hung, J. H., Kuo, Y. C., \& Kuo, L. (2006). CEO tenure in Taiwanese family and non-family firms: an agency theory perspective. Family Business Review, 19(1), 11-28.

Turban, D. B. \& Greening, D. W. (1997). Corporate Social Performance and Organizational Attractiveness to Prospective Employees. Academy of Management Journal, 40(3), 658-673.

Uhlaner, L. M., Goor-Balk, H. J. M. \& Masurel, E. (2004). Family business and corporate social responsibility in a sample of Dutch firms. Journal of Small Business and Enterprise Development, 11(2), 186-194.

Waddock, S. A. \& Graves, S. B. (1997). The corporate social performance - financial performance link. Strategic Management Journal, 18(3), 303-319.

Wagner, M. (2007). Integration of environmental management with other managerial functions of the firm: empirical effects on drivers of economic performance. Long Range Planning, 40(5), 611-628.

Waldman, D.A., Siegel, D., \& Javidan, M. (2006). Components of transformational leadership and corporate social responsibility. Journal of Management Studies, 43(8), 1703-1725.

Walls, J. L., Phan, P. \& Berrone, P. (2007). A Longitudinal Study of the Link between Corporate Governance and Environmental Strategy. Paper presented at the Sixty-Sixth Annual Meeting of the Academy of Management, Philadelphia, August 3-8.

Ward, J. L. (2004). Perpetuating the family business: 50 lessons learned from long lasting, successful families in business. Marietta, GA: Family Enterprise Publishers.

Weigelt, K., \& Camerer, C. (1988). Reputation and corporate strategy - a review of recent theory and applications. Strategic Management Journal, 9(5), 443-454. 
Whetten, D. A. \& Mackey, A. (2002). A social actor conception of organizational identity and its implications for the study of organizational reputation. Business and Society, 41(4), 393-414.

Wiklund, J. (2006). Commentary: "family firms and social responsibility: preliminary evidence from the S\&P 500". Entrepreneurship Theory and Practice, 30(6), 803-808.

Wood, D. J. (1991). Corporate social performance revisited. Academy of Management Review, $16(4), 691-718$.

Zellweger, T. M. \& Astrachan, J. H. (2008). On the emotional value of owning a firm. Family Business Review, 21(4), 347-363.

Ziegler, A. \& Seijas-Nogareda, J. (2009). Environmental management systems and technological environmental innovations: exploring the causal relationship. Research Policy, 38(4), 885893.

Ziegler, A., M. Schröder \& Rennings, K. (2007). The effect of environmental and social performance on the stock performance of European corporations. Environmental and Resource Economics, 37(4), 661-680.

Zyglidopoulos, S. C. (2004). The impact of downsizing on the corporate reputation for social performance. Journal of Public Affairs, 4(1), 11-25. 
Tables to be inserted in the text

Table 1: Univariate analysis

\begin{tabular}{|c|c|c|c|c|c|}
\hline & \multicolumn{3}{|c|}{ Mean scores } & \multicolumn{2}{|c|}{ P-values of two-sided t-tests } \\
\hline & $\begin{array}{c}\text { Family-owned } \\
\quad \text { firms } \\
(\mathrm{N}=321 \text { obs. })\end{array}$ & $\begin{array}{l}\text { Lone owner } \\
\quad \text { firms } \\
(\mathrm{N}=182 \text { obs. })\end{array}$ & $\begin{array}{c}\text { Other firms } \\
\text { (N=1,719 obs.) }\end{array}$ & $\begin{array}{l}\text { Family-owned firms } \\
\text { vs. other firms } \\
(\mathrm{N}=2,040 \text { obs. })\end{array}$ & $\begin{array}{l}\text { Lone owner firms } \\
\text { vs. other firms } \\
\text { ( } \mathrm{N}=1,901 \text { obs.) }\end{array}$ \\
\hline \multicolumn{6}{|l|}{ Social responsibility concerns $(0 ; 1 ; 2)$} \\
\hline Community & 0.04 & 0.02 & 0.10 & $<0.001$ & $<0.001$ \\
\hline Diversity & 0.27 & 0.27 & 0.24 & 0.179 & 0.364 \\
\hline Employee & 0.21 & 0.34 & 0.33 & $<0.001$ & 0.944 \\
\hline Environmental & 0.16 & 0.08 & 0.41 & $<0.001$ & $<0.001$ \\
\hline Non-US operations & 0.03 & 0.06 & 0.05 & 0.127 & 0.426 \\
\hline Product & 0.30 & 0.34 & 0.40 & 0.011 & 0.228 \\
\hline Other & 0.33 & 0.58 & 0.53 & $<0.001$ & 0.286 \\
\hline Total & 1.34 & 1.68 & 2.06 & $<0.001$ & 0.005 \\
\hline \multicolumn{6}{|l|}{ Social responsibility initiatives $(0 ; 1 ; 2)$} \\
\hline Community & 0.41 & 0.24 & 0.35 & 0.157 & 0.012 \\
\hline Diversity & 0.61 & 0.57 & 0.60 & 0.784 & 0.577 \\
\hline Employee & 0.52 & 0.65 & 0.55 & 0.345 & 0.076 \\
\hline Environmental & 0.07 & 0.09 & 0.24 & $<0.001$ & $<0.001$ \\
\hline Non-US operations & 0.04 & 0.02 & 0.03 & 0.178 & 0.702 \\
\hline Product & 0.19 & 0.36 & 0.15 & 0.084 & $<0.001$ \\
\hline Other & 0.05 & 0.12 & 0.02 & $<0.001$ & $<0.001$ \\
\hline Total & 1.89 & 1.94 & 2.05 & 0.636 & 0.374 \\
\hline
\end{tabular}


Table 2: Classical random-effects regressions on CSR concerns

Dependent variable: Social responsibility concerns (on a scale from 0 to 14)

\begin{tabular}{|c|c|c|c|c|c|c|c|c|}
\hline & \multicolumn{2}{|c|}{ Model I } & \multicolumn{2}{|c|}{ Model II } & \multicolumn{2}{|c|}{ Model III } & \multicolumn{2}{|c|}{ Model IV } \\
\hline & Coeff. (SE) & p-value ${ }^{1}$ & Coeff. (SE) & p-value $^{1}$ & Coeff. (SE) & p-value ${ }^{1}$ & Ceoff. (SE) & p-value ${ }^{1}$ \\
\hline Ownership by lone founder or family (in \%) & $-0.94(0.41)$ & 0.022 & $-0.50(0.40)$ & 0.207 & & & & \\
\hline Ownership by lone founder (in \%) & & & & & $-0.23(0.74)$ & 0.756 & $-0.44(0.77)$ & 0.570 \\
\hline Ownership by family (in \%) & & & & & $-0.57(0.45)$ & 0.201 & $-0.76(0.47)$ & 0.107 \\
\hline Lone founder CEO & & & & & & & $0.11(0.09)$ & 0.225 \\
\hline Family CEO (dummy) & & & & & & & $0.07(0.11)$ & 0.490 \\
\hline Ownership by institutional investors (in \%) & $1.00(0.26)$ & $<0.001$ & $0.22(0.22)$ & 0.307 & $0.23(0.22)$ & 0.303 & $0.26(0.22)$ & 0.234 \\
\hline Log (assets) & $0.58(0.04)$ & $<0.001$ & $0.24(0.04)$ & $<0.001$ & $0.24(0.04)$ & $<0.001$ & $0.24(0.04)$ & $<0.001$ \\
\hline Debt/ assets (in \%) & $0.16(0.19)$ & 0.420 & $0.02(0.17)$ & 0.929 & $0.02(0.17)$ & 0.931 & $0.03(0.17)$ & 0.870 \\
\hline Return on assets (in \%) & $-0.48(0.19)$ & $<0.001$ & $-0.48(0.17)$ & 0.006 & $-0.48(0.18)$ & 0.006 & $-0.47(0.18)$ & 0.009 \\
\hline Industry concerns (mean) & & & $0.78(0.03)$ & $<0.001$ & $0.78(0.03)$ & $<0.001$ & $0.79(0.03)$ & $<0.001$ \\
\hline Constant & $3.19(0.34)$ & $<0.001$ & $1.62(0.30)$ & $<0.001$ & $1.63(0.30)$ & $<0.001$ & $1.71(0.30)$ & $<0.001$ \\
\hline Obs. (firms) & $2,222(4$ & & $2,222(4$ & & $2,222($ & & $2,206(4$ & \\
\hline Obs. per firm: min.; mean; max. & $1 ; 5.5$ & & $1 ; 5.5$ & & $1 ; 5.5$ & & $1 ; 5.4$ & \\
\hline $\mathrm{R}^{2}$ within, between, overall & $0.10 ; 0.21$ & 0.19 & $0.31 ; 0.47$ & 0.43 & $0.30 ; 0.47$ & 0.43 & $0.31 ; 0.47$ & 0.43 \\
\hline $\mathrm{Chi}^{2}(\mathrm{df})$ & $289.34(5$ & $* * *$ & $975.29(6)$ & $* * *$ & 975.12 & $* * *$ & 979.78 & $* * *$ \\
\hline
\end{tabular}

$* * * \mathrm{p}<0.001 \quad$ Coeff. $=$ Coefficient; $\mathrm{SE}=$ robust standard errors

${ }^{1} \mathrm{P}$-values refer to two-sided tests

In a different regression, we also used industry dummies to control for industry influences on CSR concerns. The results are similar and can be obtained from the authors. 
Table 3: Classical random-effects regressions on CSR initiatives

Dependent variable: Social responsibility initiatives (on a scale from 0 to 14)

\begin{tabular}{|c|c|c|c|c|c|c|c|c|}
\hline & \multicolumn{2}{|c|}{ Model I } & \multicolumn{2}{|c|}{ Model II } & \multicolumn{2}{|c|}{ Model III } & \multicolumn{2}{|c|}{ Model IV } \\
\hline & Coeff. (SE) & p-value ${ }^{1}$ & Coeff. (SE) & p-value ${ }^{1}$ & Coeff. (SE) & p-value ${ }^{1}$ & Ceoff. (SE) & p-value ${ }^{1}$ \\
\hline Ownership by lone founder or family (in \%) & $0.14(0.43)$ & 0.745 & $0.04(0.39)$ & 0.922 & & & & \\
\hline Ownership by lone founder (in \%) & & & & & $-1.04(0.79)$ & 0.190 & $-0.93(0.80)$ & 0.244 \\
\hline Ownership by family (in \%) & & & & & $0.32(0.43)$ & 0.449 & $0.04(0.46)$ & 0.928 \\
\hline Lone founder CEO & & & & & & & $-0.05(0.11)$ & 0.637 \\
\hline Family CEO (dummy) & & & & & & & $0.20(0.13)$ & 0.120 \\
\hline Ownership by institutional investors (in \%) & $-0.50(0.21)$ & 0.016 & $-0.61(0.20)$ & 0.003 & $-0.61(0.20)$ & 0.002 & $-0.61(0.20)$ & 0.003 \\
\hline Log (assets) & $0.32(0.04)$ & $<0.001$ & $0.25(0.04)$ & $<0.001$ & $0.24(0.04)$ & $<0.001$ & $0.24(0.04)$ & $<0.001$ \\
\hline Debt/ assets (in \%) & $0.05(0.19)$ & 0.775 & $0.08(0.18)$ & 0.652 & $0.09(0.18)$ & 0.628 & $0.10(0.18)$ & 0.557 \\
\hline Return on assets (in \%) & $0.13(0.15)$ & 0.361 & $0.03(0.18)$ & 0.893 & $0.03(0.18)$ & 0.870 & $0.03(0.02)$ & 0.871 \\
\hline Industry initiatives (mean) & & & $0.61(0.04)$ & $<0.001$ & $0.61(0.04)$ & $<0.001$ & $0.61(0.04)$ & $<0.001$ \\
\hline Constant & $-0.90(3.25)$ & 0.011 & $-1.39(0.32)$ & $<0.001$ & $-1.37(0.32)$ & $<0.001$ & $-1.35(0.33)$ & $<0.001$ \\
\hline Obs. (firms) & $2,222(4$ & & $2,222(40$ & & $2,222(40$ & & $2,206(40$ & \\
\hline Obs. per firm: min.; mean; max. & $1 ; 5.5$ & & $1 ; 5.5 ; 1$ & & $1 ; 5.5 ; 1$ & & $1 ; 5.4 ; 1$ & \\
\hline $\mathrm{R}^{2}$ within, between, overall & $0.02 ; 0.12$ & 0.08 & $0.11 ; 0.28$ & .22 & $0.11 ; 0.27$ & .22 & $0.11 ; 0.27$ & .22 \\
\hline $\mathrm{Chi}^{2}(\mathrm{df})$ & $77.40(5)$ & & $304.25(6)$ & & $304.60(7)$ & & $303.24(8)$ & \\
\hline
\end{tabular}

$* * * \mathrm{p}<0.001 \quad$ Coeff. $=$ Coefficient; $\mathrm{SE}=$ robust standard errors

${ }^{1} \mathrm{P}$-values refer to two-sided tests

In a different regression, we also used industry dummies to control for industry influences on CSR initiatives. The results are similar and can be obtained from the authors. 
Table 4: Bayesian random-effects regressions on CSR concerns

Dependent variable: Social responsibility concerns (on a scale from 0 to 14 )

\begin{tabular}{|c|c|c|c|c|c|c|c|c|}
\hline & \multicolumn{2}{|c|}{ Model I } & \multicolumn{2}{|c|}{ Model II } & \multicolumn{2}{|c|}{ Model III } & \multicolumn{2}{|c|}{ Model IV } \\
\hline & $\begin{array}{c}\text { Median } \\
\text { Coeff. }\end{array}$ & $\begin{array}{c}\text { Prob. Co- } \\
\text { eff }>0\end{array}$ & $\begin{array}{c}\text { Median } \\
\text { Coeff. }\end{array}$ & $\begin{array}{c}\text { Prob. Co- } \\
\text { eff }>0\end{array}$ & $\begin{array}{c}\text { Median } \\
\text { Coeff. }\end{array}$ & $\begin{array}{c}\text { Prob. Co- } \\
\text { eff }>0\end{array}$ & $\begin{array}{c}\text { Median } \\
\text { Coeff. }\end{array}$ & $\begin{array}{c}\text { Prob. } \\
\text { Coeff }>0\end{array}$ \\
\hline Ownership by lone founder or family (in \%) & -1.06 & $4.5 \%$ & -0.88 & $6.9 \%$ & & & & \\
\hline Ownership by lone founder (in \%) & & & & & -1.81 & $5.9 \%$ & -1.93 & $4.9 \%$ \\
\hline Ownership by family (in \%) & & & & & -0.62 & $17.7 \%$ & -1.17 & $3.5 \%$ \\
\hline Lone founder CEO (dummy) & & & & & & & 0.14 & $86.4 \%$ \\
\hline Ownership by institutional investors (in \%) & 1.01 & $100 \%$ & 0.24 & $84.5 \%$ & 0.23 & $84.3 \%$ & 0.30 & $90.5 \%$ \\
\hline Log (assets) & 0.66 & $100 \%$ & 0.12 & $99.1 \%$ & 0.11 & $97.9 \%$ & 0.12 & $99.0 \%$ \\
\hline Debt/ assets (in \%) & -0.09 & $34.5 \%$ & -0.04 & $41.9 \%$ & -0.02 & $46.1 \%$ & 0.01 & $51.8 \%$ \\
\hline Return on assets (in \%) & -0.54 & $0.6 \%$ & -0.53 & $0.2 \%$ & -0.51 & $0.4 \%$ & -0.51 & $0.3 \%$ \\
\hline Industry concerns (mean) & & & 0.78 & $100 \%$ & 0.78 & $100 \%$ & 0.79 & $100 \%$ \\
\hline Obs. (firms) & 2,222 & $(406)$ & 2,22 & $(406)$ & 2,22 & $(406)$ & 2,20 & $(405)$ \\
\hline Obs. per firm: min., mean, max. & $1 ; 5$ & $; 10$ & $1 ; 5$ & $5 ; 10$ & 1 & $; 10$ & $1 ; 5$ & $; 10$ \\
\hline
\end{tabular}

Notes: We use normally distributed priors with a mean of zero and a standard deviation of one. Number of draws: 10,000 (the first 1,000 draws are discarded).. The Matlab code used to run the regressions can be requested from the authors.

In a different regression, we also used industry dummies to control for industry influences on CSR concerns. The results are similar and can be obtained from the authors. 
Table 5: Bayesian random-effects regressions on CSR initiatives

Dependent variable: Social responsibility initiatives (on a scale from 0 to 14 )

\begin{tabular}{|c|c|c|c|c|c|c|c|c|}
\hline & \multicolumn{2}{|c|}{ Model I } & \multicolumn{2}{|c|}{ Model II } & \multicolumn{2}{|c|}{ Model III } & \multicolumn{2}{|c|}{ Model IV } \\
\hline & $\begin{array}{c}\text { Median } \\
\text { Coeff. }\end{array}$ & $\begin{array}{c}\text { Prob. Co- } \\
\text { eff }>0\end{array}$ & $\begin{array}{c}\text { Median } \\
\text { Coeff. }\end{array}$ & $\begin{array}{c}\text { Prob. Co- } \\
\text { eff }>0\end{array}$ & $\begin{array}{c}\text { Median } \\
\text { Coeff. }\end{array}$ & $\begin{array}{c}\text { Prob. Co- } \\
\text { eff }>0\end{array}$ & $\begin{array}{c}\text { Median } \\
\text { Coeff. }\end{array}$ & $\begin{array}{c}\text { Prob. } \\
\text { Coeff }>0\end{array}$ \\
\hline Ownership by lone founder or family (in \%) & 0.28 & $69.2 \%$ & 0.16 & $62.0 \%$ & & & & \\
\hline Ownership by lone founder (in \%) & & & & & -1.79 & $3.7 \%$ & -1.65 & $7.0 \%$ \\
\hline Ownership by family (in \%) & & & & & 0.66 & $84.5 \%$ & 0.48 & $79.1 \%$ \\
\hline Lone founder CEO (dummy) & & & & & & & -0.14 & $11.7 \%$ \\
\hline Ownership by institutional investors (in \%) & -0.35 & $5.7 \%$ & -0.45 & $1.7 \%$ & -0.45 & $1.4 \%$ & -0.46 & $1.8 \%$ \\
\hline Log (assets) & 0.29 & $100 \%$ & 0.19 & $100 \%$ & 0.18 & $100 \%$ & 0.18 & $100 \%$ \\
\hline Debt/ assets (in \%) & 0.15 & $77.9 \%$ & 0.13 & $76.0 \%$ & 0.17 & $81.4 \%$ & 0.22 & $86.9 \%$ \\
\hline Return on assets (in \%) & -0.01 & $49.0 \%$ & -0.14 & $22.3 \%$ & -0.12 & $25.9 \%$ & -0.11 & $26.8 \%$ \\
\hline Industry initiatives (mean) & & & 0.55 & $100 \%$ & 0.56 & $100 \%$ & 0.56 & $100 \%$ \\
\hline Obs. (firms) & 2,222 & $(406)$ & 2,22 & $(406)$ & 2,22 & $(406)$ & 2,20 & $(405)$ \\
\hline Obs. per firm: min., mean, max. & $1 ; 5$ & $; 10$ & $1 ; 5$ & $5 ; 10$ & 1 & $; 10$ & $1 ; 5$ & $; 10$ \\
\hline
\end{tabular}

Notes: We use normally distributed priors with a mean of zero and a standard deviation of one. Number of draws: 10,000 (the first 1,000 draws are discarded).. The Matlab code used to run the regressions can be requested from the authors.

In a different regression, we also used industry dummies to control for industry influences on CSR initiatives. The results are similar and can be obtained from the authors. 
Figures 1-8: Posterior distributions of the coefficients of the family and founder firm variables

Figure 1:

Effect of family ownership on CSR concerns

$\mathrm{P}(ß)$

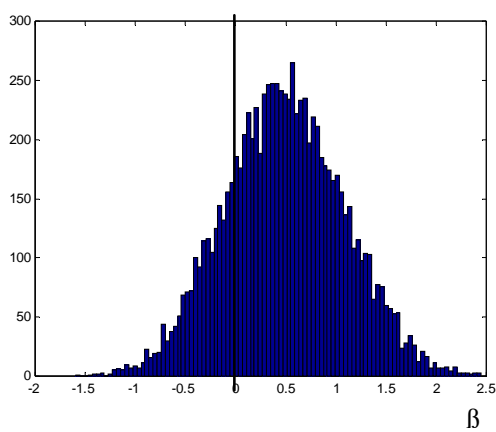

Figure 5

Effect of family ownership on CSR strengths

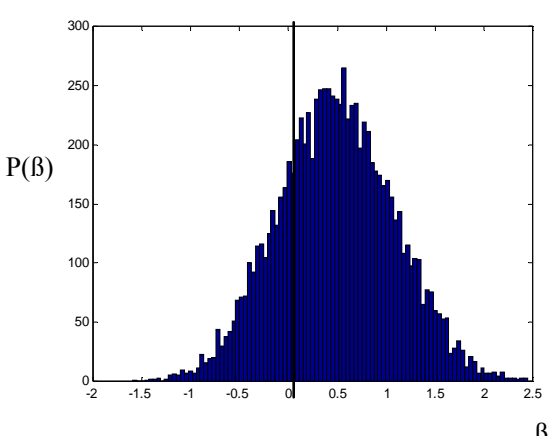

Figure 2:

Effect of lone founder ownership on CSR concerns

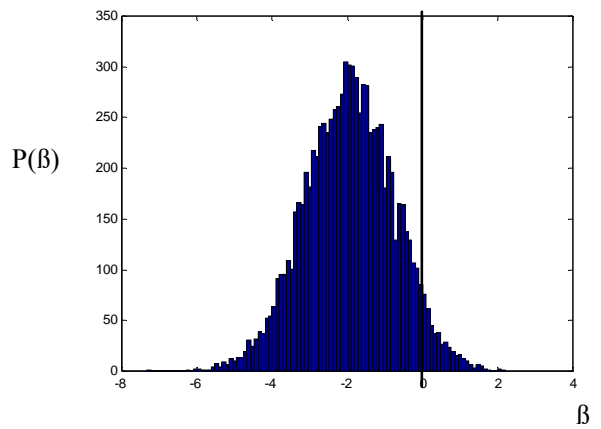

Figure 6:

Effect of lone founder ownership on CSR strengths

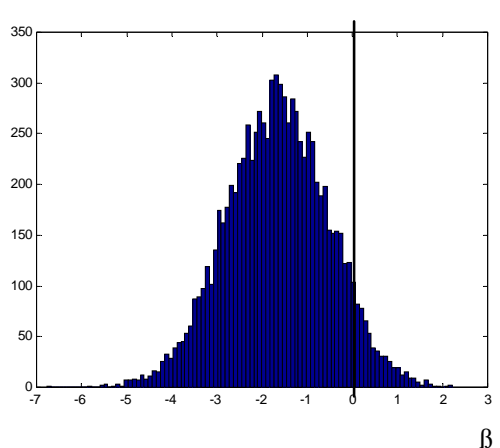

Figure 3:

Effect of family CEO on CSR concerns

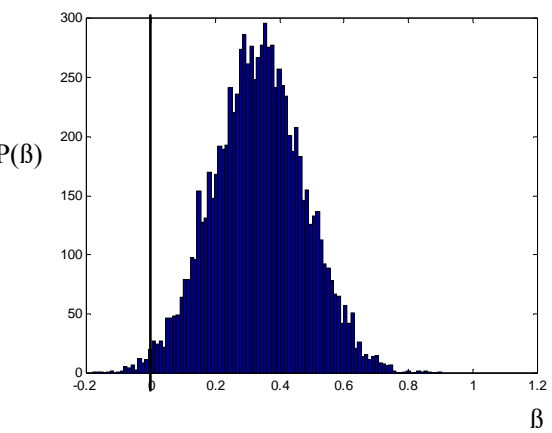

Figure 7:

Effect of family CEO on CSR strengths

$\mathrm{P}(ß)$

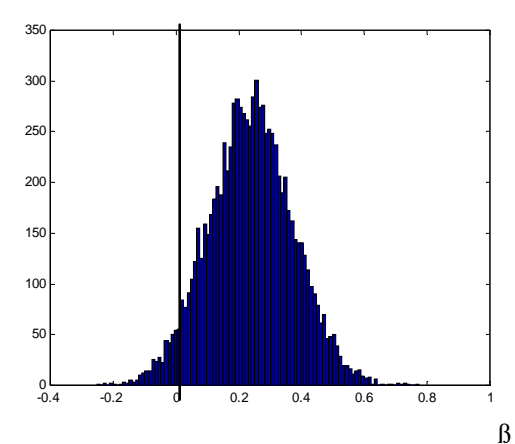

Figure 4:

Effect of lone founder CEO on CSR concerns

$\mathrm{P}(ß)$

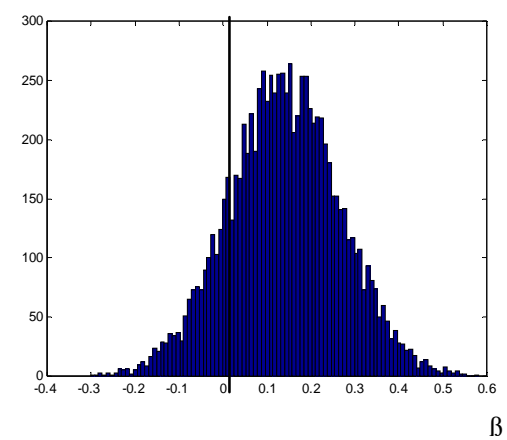

Figure 8:

Effect of lone founder CEO on CSR strengths

$P($ (B)

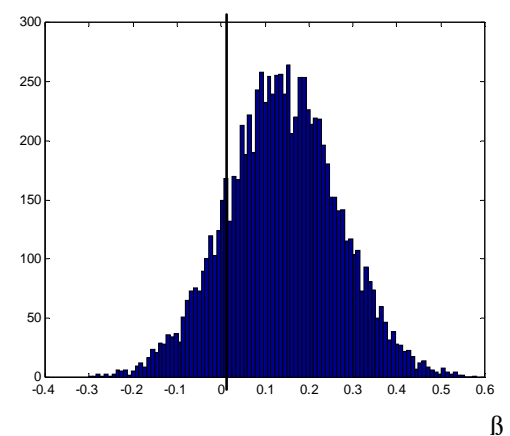




\section{Appendix}

\section{Table A1: Descriptive statistics and correlations}

\begin{tabular}{|c|c|c|c|c|c|c|c|c|c|c|c|c|c|c|c|c|}
\hline & Min. & Max & Mean & Median & 1 & 2 & 3 & 4 & 5 & 6 & 7 & 8 & 9 & 10 & 11 & VIF \\
\hline 1 Social responsibility concerns & 0 & 9 & 1.93 & 2 & & & & & & & & & & & & \\
\hline 2 Social responsibility initiatives & 0 & 8 & 1.94 & 2 & 0.10 & & & & & & & & & & & \\
\hline 3 Ownership by lone founder (in \%) & 0 & 0.65 & 0.01 & 0 & -0.02 & -0.01 & & & & & & & & & & 1.31 \\
\hline 4 Ownership by family (in \%) & 0 & 0.77 & 0.04 & 0 & -0.13 & -0.02 & -0.08 & & & & & & & & & 1.30 \\
\hline 5 Lone founder CEO (dummy & 0 & 1 & 0.10 & 0 & -0.05 & 0.05 & 0.46 & -0.07 & & & & & & & & 1.30 \\
\hline 6 Family CEO (dummy) & 0 & 1 & 0.08 & 0 & -0.13 & 0.01 & -0.06 & 0.40 & -0.10 & & & & & & & 1.20 \\
\hline 7 Ownership by institutional investors (in \%) & 0 & 0.85 & 0.13 & 0.12 & -0.00 & -0.16 & -0.11 & -0.22 & -0.09 & -0.09 & & & & & & 1.15 \\
\hline 8 Log (assets) & 5.85 & 13.83 & 8.84 & 8.61 & 0.42 & 0.27 & 0.01 & -0.14 & -0.08 & -0.09 & -0.18 & & & & & 1.29 \\
\hline 10 Return on assets (in \%) & -4.58 & 0.54 & 0.05 & 0.05 & -0.15 & 0.03 & 0.03 & 0.07 & -0.01 & 0.02 & -0.04 & -0.20 & -0.13 & & & 1.06 \\
\hline 11 Industry concerns (mean) & & & & & 0.61 & 0.05 & -0.05 & -0.13 & -0.05 & -0.04 & 0.01 & 0.31 & 0.23 & -0.10 & & 1.15 \\
\hline 12 Industry initiatives (mean) & & & & & 0.07 & 0.42 & 0.00 & 0.02 & 0.06 & 0.01 & -0.05 & 0.13 & -0.04 & 0.01 & 0.11 & \\
\hline
\end{tabular}

Notes: VIF=Variance inflation factor (referring to the regression with CSR concerns as dependent variable (Tables 2 and 4); $\mathrm{N}=2,206$ obs.; all correlations above $\mathrm{r}=0.04$ or below $\mathrm{r}=-0.04$ have a $\mathrm{p}$-value less than 0.05 . 
Table A2: Description of variables

Variable

Description

Dependent variables

Social responsibility concerns

Sum of community concerns, diversity concerns, employee concerns, environmental concerns, non-US operations concerns, product concerns, and other concerns (source: social performance rating service KLD; individual concerns are rated $0,1,2)$.

Sum of community initiatives, diversity initiatives, employee initiatives,

Social responsibility initiatives environmental initiatives, non-US operations initiatives, product initiatives, and other initiatives (source: social performance rating service KLD; individual concerns are rated 0,1,2).

\section{Variables of interest}

Ownership by lone founder (in \%)

Percentage of common stock owned by lone founder; a lone founder is an individual who is one of the company's founders; in these firms, there exist no other family members who own more than $5 \%$ of the issued stock; a firm with lone founder ownership thus cannot be a firm with family ownership, nor vice-versa (source: manual data collection from the SEC Edgar database)

Ownership by family (in \%)

Percentage of common stock owned by members of the founding family; at least two family members are owners (source: manual data collection from the SEC Edgar database)

Lone founder CEO (dummy

Dummy=1 if lone founder is CEO; for the definition of lone founder see ownership share of lone founder variable (source: manual data collection from the SEC Edgar database)

Dummy $=1$ if member of the family is CEO; for the definition of family,

Family CEO (dummy) see ownership share of family variable (source: manual data collection from the SEC Edgar database)

Percentage of stock owned by institutional investors; institutional inves-

Ownership by institutional investors (in \%) tors can include large banks, insurance companies or mutual funds (source: manual data collection from the SEC Edgar database)

\section{Control variables}

Log (assets)

Debt/ assets (in \%)

Return on assets (in \%)

Industry concerns (mean)

Industry initiatives (mean)
Natural logarithm of total assets (source: Compustat North America; data item: AT)

Long-term debt (in millions of US\$) divided by total assets (in millions of US\$) (source: Compustat North America; data items: AT, DT)

Income before extraordinary items divided by total assets (in millions of US \$) (source: Compustat North America; data items: AT, IBCOM)

Mean number of social responsibility concerns in the firm's 2-digit SIC industry

Mean number of social responsibility initiatives in the firm's 2-digit SIC industry 


\section{Appendix A3: Detailed description of Bayesian analysis}

For the prior distribution of the individual effects, we choose a normal distribution. This corresponds to a random-effects model specification in classical econometrics. For the coefficients, we assume a normally distributed prior with a mean of zero for all coefficients. Such a prior specification would imply that our model has no explanatory power at all, which ensures that any evidence for the existence of a particular effect is not induced by the specification of the prior. Furthermore, our particular prior specification ensures that the posterior distributions functions are identifiable, i.e. we are not ending up with a flat posterior distribution (Koop, 2003, p. 291). Finally, the prior of the variance is assumed to follow a $\chi^{2}$ distribution, which is consistent with the assumption of normally distributed error terms.

As a check of the robustness of the results, we also estimated our model with different prior specifications. We allowed for different means and variances in the normal distribution and for different classes of distributions such as a uniform distribution. Regardless of the prior specifications chosen, we obtained basically the same results.

For the estimation, we used a Matlab code which takes 11,000 draws from the posterior distribution (as usual the first 1,000 draws are discarded). As the estimation ends up in a multidimensional posterior distribution, we applied the Gibbs Sampler to arrive at the corresponding univariate distributions of the coefficients shown in Table 4 and 5, respectively. The Matlab code is available from the authors. 


\section{Publications in the ERIM Report Series Research* in Management}

\section{ERIM Research Program: "Organizing for Performance"}

2010

Investigating the Perceptions of Credit Constraints in the European Union

Erik Canton, Isabel Grilo, Josefa Monteagudo, and Peter van der Zwan

ERS-2010-001-ORG

http://hdl.handle.net/1765/17699

Two Lighthouses to Navigate: Effects of Ideal and Counter-Ideal Values on Follower Identification and Satisfaction with their Leaders

Niels van Quaquebeke, Rudolf Kerschreiter, Alice E. Buxton, and Rolf van Dick

ERS-2010-003-ORG

http://hdl.handle.net/1765/17702

Genome-wide Association Studies and the Genetics of Entrepreneurship

Matthijs J.H.M. van der Loos, Philipp D. Koellinger, Patrick J.F. Groenen, and A. Roy Thurik

ERS-2010-004-ORG

http://hdl.handle.net/1765/17757

How embodied cognitions affect judgments: Height-related attribution bias in football foul calls

Niels van Quaquebeke and Steffen R. Giessner

ERS-2010-006-ORG

http://hdl.handle.net/1765/17827

Flexible Labor and Innovation Performance: Evidence from Longitudinal Firm-Level Data

Haibo Zhou, Ronald Dekker, and Alfred Kleinknecht

ERS-2010-007-ORG

http://hdl.handle.net/1765/18037

The Influence of Installed Technologies on Future Adoption Decisions: Empirical Evidence from E-Business

Philipp Koellinger and Christian Schade

ERS-2010-012-ORG

http://hdl.handle.net/1765/18463

Seeds of Regional Structural Change: The Role of Entrepreneurs and Expanding Firms in Shaping Local Path Dependencies

Frank Neffke and Martin Henning

ERS-2010-014-ORG

http://hdl.handle.net/1765/19207

Determinants of Contractual Completeness in Franchising

George Hendrikse and Josef Windsperger

ERS-2010-017-ORG

http://hdl.handle.net/1765/19424

Agglomeration and New Establishment Survival: A Mixed Hierarchical and Cross-Classified Model

Martijn J. Burger, Frank G. van Oort, and Otto Raspe

ERS-2010-018-ORG

http://hdl.handle.net/1765/19519

Corporate Social Responsibility in Large Family and Founder Firms

Joern Block and Marcus Wagner

ERS-2010-027-ORG

http://hdl.handle.net/1765/20273 
The Social Capital of Venture Capitalists and Its Impact on the Funding of Start-Up Firms Oliver Alexy, Joern H. Block, Philipp Sander, and Anne L.J. Ter Wal

ERS-2010-028-ORG

http://hdl.handle.net/1765/20274

* A complete overview of the ERIM Report Series Research in Management: https://ep.eur.nl/handle/1765/1

ERIM Research Programs:

LIS Business Processes, Logistics and Information Systems

ORG Organizing for Performance

MKT Marketing

F\&A Finance and Accounting

STR Strategy and Entrepreneurship 